\title{
The Significance of Internal and External Relativism for Religious Harmony
}

\section{Zaprulkhan}

Prodi PAI Pascasarjana, IAIN Syaikh Abdurrahman Siddik Bangka, Indonesia

zaprulkhan_zahra@yahoo.co.id

\begin{abstract}
In the public sphere, internal relations between fellow Muslims appear negative. Some Muslims insult, curse and slander each other. Likewise, relations between religious communities externally show a less harmonious relationship. There is mutual suspicion in the relationship between religious communities externally. Some Muslim scholars offer the concept of internal relativism as a solution for relations between fellow Muslims internally and the concept of external relativism as a solution for relations between various religious communities in the public space. Therefore, this article tries to elaborate on the significance of the construction of internal and external relativism in building ukhuwah Islamiyah internally and harmony among religious communities externally.
\end{abstract}

Keywords; significance, internal and external relativism, religious harmony

\begin{abstract}
Abstrak:
Dalam ruang publik, relasi internal antara sesama umat Islam tampak negatif. Sebagian umat Islam saling mencaci menjelekkan satu sama lain, saling mengutuk dan memfitnah. Begitu pula, relasi antara umat beragama secara eksternal memperlihatkan hubungan yang kurang harmonis. Ada sikap saling curiga dalam hubungan antara umat beragama secara eksternal. Sebagian cendikiawan muslim menawarkan konsep relativisme internal sebagai solusi bagi relasi antara sesama umat Islam secara internal dan konsep relativisme eksternal sebagai solusi bagi relasi antara berbagai umat beragama di ruang publik. Karena itu, artikel ini mencoba untuk menguraikan signifikansi konstruksi relativisme internal dan eksternal dalam membangun ukhuwah islamiyah secara internal dan kerukunan antar umat beragama secara eksternal.
\end{abstract}

Kata kunci, signifikansi, relativisme internal dan eksternal, harmoni agama

Received: 07-11-2020; accepted: 15-11-2020; published: 10-12-2020

Citation: Zaprulkhan, 'The Significance of Internal and External Relativism for Religious Harmony', Mawa'izh: Jurnal Dakwah dan Pengembangan Sosial Kemanusiaan, vol. 11, no. 2 (2020), pp. 154-168. 


\section{A. Introduction}

The atmosphere of relations between fellow Muslims in the public space has recently painted an uncomfortable atmosphere. The proliferation of various forms of social media networks, has not made it easier for Muslims to establish better and positive social relationships, but has instead fostered worse and negative social relations between our neighbors. Not a few of their fellow Muslims are hostile to each other, berate and vilify, curse one another and even slander; So that in the end the Muslims became increasingly divided, and they lost their strength of unity and integrity. In this condition, the ukhuwah Islamiyah discourse finds a moment of relevance and actuality again.

When talking about the fabric of ukhuwah Islamiyah, brotherhood among Muslims, one of the concepts offered by some Muslim scholars and scholars is the principle of internal relativism. Internal relativism talks about the very diverse internal relations among Muslims. Internal relativism is an attitude of inward relativity, without claims of absolutes against oneself and one's own group. When we meet Muslims who have different understandings, views, or some aspects of their beliefs, then we should not impose our understanding, views and beliefs on them.

Meanwhile, when talking about inter-religious harmony, one of the concepts offered by some Muslim scholars and scholars is the principle of external relativism. If internal relativism talks about the very diverse internal relations between fellow Muslims, external relativism describes the relations between Muslims and non-Muslim communities which are also very diverse. This article seeks to examine the significance of the construction of internal and external relativism in building ukhuwah Islamiyah internally and externally inter-religious harmony.

\section{B. Discourse of Internal and External Relativism}

First of all we must understand that relativism here does not mean a rejection of the existence of general standards, fundamental religious values, and the principles of creed. In Amin Abdullah's perspective, religious communities consider relativism to be a scourge that is very feared and must be shunned at the same time. Relativism has a very "negative" face and is something that must be rejected. Why? Because in their imagination, relativism must mean the absence of strong, firm, and standardized standards of faith or values or rejection of "general truths". Relativism should be 
identified with moral nihilism and value vacuum. Implicitly and even explicitly, relativism also implies that all opinions, views, and beliefs of religions have "equal values".

Due to the various negative connotations, religious people tend to reject the notion of pluralism - especially in the area of religions - and prefer to prefer an "exclusive" attitude and prioritize truth claims. Without realizing it, even this choice within limits that are beyond reasonableness - can easily lead a person or group to a fundamentalist attitude, extremism, and radicalism. The question is "how ugly and scary is the face and image of" relativism? "

For Amin Abdullah, awareness of the "plurality" of religions is a healthy religious view and does not violate the main teachings of the Al-Qur'an. A view that supports "relativity or relativism". Relativity or relativism here is understood not to be as scary as described above. Relativism here is understood as a way to "open up an opportunity for the understanding of an object from various existing dimensions and aspects". So, relativism is not understood as an attitude of total rejection of the values of certain standard religious teachings. ${ }^{1}$

Relativism here does not mean total rejection of the existence of general standards, religious fundamental values, monotheistic principles and so on. Relativism here, is intended more as a "technical-methodological" term which is very much needed in the world of understanding, interpretation and meaning because the term is intended as a description or portrait of the reality of how different cultures, religions, languages, and traditions describe the world - including the world of religious reality - which also differs from one another. The fact that there is a strong relationship between "thought" and "object of thought" (which is plural) is an affirmation of the need for steps and understanding "procedures" to be followed, and not a symbol of emptiness or moral decisions.

Thus, the problem of relativism here is more related to the "methodological" aspect, and not to the metaphysical problem. Relativism here is related to the need for a practical interpretive "model" and "framework of understanding", not an objective statement about the nature of the world around humans. Therefore, consequently, the "model" or "framework" of understanding and interpretation is not an opinion that is

${ }^{1}$ M. Amin Abdullah, Dinamika Islam Kultural, (Bandung: Mizan, 2000), p. 81-82. 
"fixed" (unchanging), but simply a "model" or "framework" of approach to explain the essence of something.

Therefore, the relativism referred to here does not mean "meaninglessness" (moral nihilism) or is also "value vacuum" and moreover not as "faith emptiness" - as is commonly understood and voiced by many people. However, it is actually more of a serious and authentic effort, especially for all religious communities to understand and develop a deeper "meaning" and "value" shared by various ethnic groups, races, religions, and so on. This seems to be more conducive to anticipating the challenges of changing times.

It needs to be emphasized once again that relativism here is positive, not negative. It only reinforces the need for a frame of reference or framework, a framework of thought, a pattern of approach, and an analysis method in an effort to understand and select objects - in this case the phenomenon of human diversity - not a rejection of the opinion that a reference or framework is like something real. In understanding the meaning of such relativism, it does not automatically mean that everything (including descriptions of religious life) "is only" in the brain or in the understanding itself, or in other words that the reality of the world (religion) is "only" in view. ${ }^{2}$ Thus there is no "objective" religious reality (beyond the view of individuals), but this further underlines the fact that the reality of the religious world is so "large", "vast" and "complex" - multilayered affair - so that humans need to "select" and map them.

Thus, a person or group can only understand or accept "certain aspects" of religious realities that have been caught by them. The value of the benefits of understanding the importance of "relativism" lies not in the raw rejection of the existence of "common knowledge", but rather in the need to acknowledge and explain differences in understanding reality. Such views and understanding of the meaning and meaning of relativism can help and encourage humankind to become more self-reflective and selfcorrective, as well as being responsible for the "language", "thoughts" and "actions" we choose, which are often "Interpretative".

So relativity here is only technical-methodological in nature which is needed in building tolerance, religious moderation, harmony, and social cooperation between 
various religious communities. ${ }^{3}$ In the matter of relativism this is more related to methodological aspects, not to the metaphysical dimension. Relativism at this level, to borrow Nasr Hamid's term in Mafhum Nash, is cultural relativism (an-Nisbiyah atsTsaqofiyah) not substantial relativism (an-Nisbiyah adz-Dzatiyah). ${ }^{4}$

At this point, we enter the concept of internal relativism. Simply put, internal relativism is an attitude of humility that recognizes the truth of beliefs, perspectives, understandings, or views internally among very diverse Muslims.

As a result, understanding the need for "relativism" actually helps every religious person to think, act and have a more "sacred" attitude (humanity); not overdoing it, not exceeding limits, not overacting, and not being too enthusiastic so that it violates the boundaries of reasonableness in religion. Isn't the Koran always insinuating and advising people not to always "exaggerate" in everything with the term ghulw?

Tentatively-subjective, Amin Abdullah "claims" that the attitude and response of the Qur'an to the issue of plurality of religions is similar to the attitude of assuming that "Truth" — with a large T — does exist. However, unfortunately only a "small part" of the Truth — with a small $\mathrm{t}$ - can be understood, obtained, achieved, and enjoyed by mankind in general and religious people in particular. ${ }^{5}$ Most of these "Truths" are not or have not been reached by the human mind because of the limitations of "language", "mind", "culture", "education" and so on. ${ }^{6}$

This wise attitude seems to be parallel to the deepest meaning of the verses of the Qur'an in Surah Al-Kahf verse 110 as follows:

Say: "I am but a man like yourselves, (but) the inspiration has come to me, that your God is one God. whoever expects to meet his Lord, let him work righteousness, and, in the worship of his Lord, admit no one as partner".(Al-Kahf: $110)^{7}$

\footnotetext{
${ }^{3}$ However, the concept of relativism here should not be confused with the concept of relativism in the atheistic philosophy which says that every truth is of relative value and that no single truth is absolute at any level. See J. Sudarminta, Epistemologi Dasar (Yogyakarta: Pustaka Filsafat, 2002), p. 55-60.

${ }^{4}$ Nasr Hamid abu Zayd, Mafhum al-Nash (Beirut: Markaz al-Saqafi al-'Arabi, 1994), p. 18.

${ }^{5}$ Compare with Haryatmoko, Dominasi Penuh Muslihat (Jakarta: Gramedia, 2010), p. 102-105.

${ }^{6}$ Ibid., p. 84.

${ }^{7}$ Abdullah Yusuf Ali, Holy Qur'an: Text, Translation and Commentary, (Maryland: Amana Corporation,
} 1983), p. 199. 
This verse truly provides extraordinary and limitless inspiration, as well as encourages mankind to do their best according to the measurement of the historical period and the challenges of the social struggles it has been through. If the verse can give a glimmer of "truth", then the truth - with a small $t$ - must be able to be tested by the Community of religious Studies, Community of Researchers in general. There is no claim there because all the "truths" that can be reached by humans are only "partial", "intellectual", and "fragmentary" truths, namely truths with small t. That way, the truth needs to be continually explored, re-discussed, criticized, tested with a cool head, and understood wisely. 8

Borrowing the hermeneutic-deconstructive analysis of the renowned contemporary Muslim scientist from Lebanon, Ali Harb, the discourse of the Koran is indeed a word that has a broad meaning and has multiple sides of significance. Al-Quran is a sacred word of God that cannot be depleted or limited in significance. No one is able to grasp the truth of the meaning of the Koran completely; The truth will never be final.

For Ali Harb, every text, especially the sacred text of the Most Plenary Divine Kalam, does not deserve to be limited to one method, one approach, one reading model, or only one interpretation of an sich. Thus, hermeneutical reading does not merely reveal the various meanings of the text, but rather a reading that seeks to uncover the significance of the text's pluralistic meaning and through a pluralistic reading approach as well. From this, the emergence of different interpretations, differences in methods and schools of thought, as well as the emergence of various schools of belief and conceptual understanding.

For this reason, in Ali Harb's hermeneutical reading paradigm, the characteristics of a text that is worth reading are not text that only contains available, closed, and final significance, but a semantic space that is always open to various meanings, a game arena that always presents new meanings that are readily available. never ending, and the horizon of meaning which is never ended with a dot (.), but a delay which is always indicated by a comma (,). The fixed meaning is undecidable. The definite meaning can no longer be decided rigidly.

\footnotetext{
8 Ibid., p. 87-88.
} 
Furthermore, with Ali Harb's deconstructive analysis, in reading the text we also enter a moment of suspension, a moment of delay. Do not take it wrong. It's not that the meaning doesn't exist. It's not that meaning can't be embraced. We can still grasp meaning. But the meaning that we have embraced we postpone it first. We remain open and keep trying to parse new meanings and meanings that are very diverse in order to enrich the truth of the meaning we have grasped. Here, reading is not to seek certainty, but rather to surf in the middle of an ocean of "uncertainty". Uniquely, when we are able to enjoy a moment of suspension, we will feel the passion of uncertainty as pledged by literary theorists: "The most precious thing in life is its uncertainty."

So the truth of the Koran is always immersed, because the text of the Koran is richer, the area is wider, the level is further, and the meaning is more diverse. Based on these arguments, for Ali Harb there is no room to blame others; there is no room to deceive and mislead others; there is no room for disbelieving and annoying different people; and there is no room for self-righteousness and absolute self-view by removing the views of others.

Because God's word is always open to similarity and difference, unity and diversity, as well as to harmony and contradiction. In God's word, there are commands and reason, inspiration and argument, news and views, consensus and opinion, text and context, coercion and submission, justice and novelty, politics and ascetics, authority and mercy, humanity and divinity, kings and angels, and therefore in it there is also discussion about religion and the world. Thus, it includes all discourses, includes all differences, and therefore, there is no room to narrow the broad by claiming absolute truth unilaterally. ${ }^{9}$

Furthermore, the construction of internal and external relativism rests on the principle of difference between human beings as God's decree, as sunnatullah. This sunnatullah also includes internal differences among Muslims. In the Koran, there are various verses that describe the differences between mankind as sunnatullah. Let us consider one of the verses that is relevant to our discussion:

If thy Lord had so willed, He could have made mankind one people: but they will not cease to dispute. Except those on whom thy Lord hath bestowed His

${ }^{9}$ See Zaprulkhan, Signifikansi Epistemologi Pembacaan Hermeneutis Ali Harb (Yogyakarta: Idea Press, 2017), p. 8-10. 
Mercy: and for this did He create them: and the Word of thy Lord shall be fulfilled: "I will fill Hell with jinns and men all together" (Hud 11: 118-119)10

From this verse, we can draw several messages: (1) God does not want humans to be singular or monolithic; (2) Humans will continue to be at odds; (3) Those who are not in conflict are those who receive the grace of God; (4) For that design God created man; (5) This sentence of God's decision or decision has been perfect, it will not change; (6) Happiness and eternal misery are concerned with the problem of differences between human beings and their differences.

That is God's Law (sunnat-u'l-Lah, sunatullah) for humans. God's statute law will not change forever. So it is eternal or perennial and immutable. Because of its eternal nature, sunatullah can be guided and used as a basis for humanitarian action in living life and facing life's problems".11

Since the difference between human beings is sunatullah, it is very logical that God's teachings on brotherhood based on faith are given within the framework of plurality (plurality), not oneness (monolithic). This is because the law of difference that God has established for mankind also applies to the believers themselves. However, the faithful are composed of individuals with different biographical, educational, social and cultural backgrounds. The brotherhood based on faith or ukhuwah Islamiyah within the framework of pluralism is clearly taught by God in a series of His words:

"If two parties among the Believers fall into a quarrel, make ye peace between them: but if one of them transgresses beyond bounds against the other then fight ye (all) against the one that transgresses until it complies with the command of Allah; but if it complies then make peace between them with justice and be fair: for Allah loves those who are fair (and just). The Believers are but a single Brotherhood: So make peace and reconciliation between your two (contending) brothers; and fear Allah, that ye may receive Mercy.

o ye who believe! Let not some men among you laugh at others: It may be that the (latter) are better than the (former): Nor let some women laugh at others: It may be that the (latter are better than the (former): Nor defame nor be sarcastic to each other, nor call each other by (offensive) nicknames: Illseeming is a name connoting wickedness, (to be used of one) after he has believed: And those who do not desist are (indeed) doing wrong.

o ye who believe! Avoid suspicion as much (as possible): for suspicion in some cases is a sin: And spy not on each other behind their backs. Would any of you like to eat the flesh of his dead brother?Nay, ye would abhor it...But fear Allah.

${ }^{10}$ Abdullah Yusuf Ali, Holy, p. 143.

${ }^{11}$ Nurcholish Madjid, Masyarakat Religius (Jakarta: Paramadina, 2000), p. 25-26. 
For Allah is Oft-Returning, Most Merciful. O mankind! We created you from a single (pair) of a male and a female, and made you into nations and tribes, that ye may know each other (not that ye may despise (each other). Verily the most honoured of you in the sight of Allah is (he who is) the most righteous of you. And Allah has full knowledge and is well acquainted (with all things)" (Al-Hujurat: 9-13) ${ }^{12}$

This is a line of holy words that we must understand regarding the teachings of brotherhood based on faith or Islamic brotherhood. Apart from affirming the principle that all believers are brothers, this line of words also provides concrete and practical instructions on how to maintain brotherhood among believers. If we try to specify in our everyday language, the teachings of God are as follows:

1. All believers are siblings to one another.

2. But believers are not all alike in all respects. The existence of differences may lead to contention; So that what must always be strived for peace.

3. The reconciliation between the two warring groups was in the framework of submitting to God.

4. With that piety, God will bestow His mercy which underlies the spirit of brotherhood.

5. Then there must be an attitude of mutual respect, by not demeaning another group.

6. Each class must be humble enough to admit the possibility of them being wrong, and the others being right.

7. In line with that, it is forbidden to insult fellow believers.

8. It is also prohibited to give mock names to each other, especially if ridicule is a crime.

9. Those who do not follow it all are wrongdoers.

10. Believers should keep a lot of prejudice away, for they can take a evil form.

11. It is also forbidden to find fault with each other.

12. And it is also prohibited to swear (ghibah, back bitting), namely talking about the badness of each other when what is being discussed is not in the place of discussion.

${ }^{12}$ Abdullah Yusuf Ali, Holy, p. 366. 
13. Doing backbiting is like eating the flesh of your own corpse, because the person who speaks of his badness, because he is not there, cannot defend himself, let alone fight. So backbiting is a double crime, a crime above evil.

14. Once again, we, the believers, are called to always fear God, that is, we are aware of God's supervision, which is always present wherever we are, so that it is not appropriate for a believer to do something that is not permitted by Him.

15. Being devoted to God results in guidance towards that noble character, so God will forgive us and give His mercy to us.

16. Furthermore, we are reminded that all mankind was created by God differently, because He made them nations and tribes.

17. It is none other than so that we know each other with mutual respect (the broad meaning of the Arabic word ta'aruf).

18. We must not divide humans into higher and lower ranks due to ascriptive or immoral considerations, such as nationality, ethnicity, and so on.

19. Because in God's sight, the height and the low of man is only based on the level of piety that has been obtained.

20. Humans will not know and are not allowed to judge or measure the level of piety among others. God is the All-Knowing and the Most Thorough. ${ }^{13}$

Does every religion contain absolute truth that cannot be questioned again? If the answer is, "yes", the next question is whether absolute truth must be pledged out in its interactions with adherents of different religions, even though it will result in clash, or conflict with one another? Or is the truth contained in every religion only relative? These questions are actually related to the principles of relations between religious communities externally and internally which lead religious communities to meet the concepts of absolutisity and external relativism.

Regarding this and related to the significance of the Islamic perspective for religious moderation and for building religious harmony in the Indonesian context, there are at least two levels of meaning that need to be discussed. First, on a personal level, every religion requires absolute truth for its respective adherents that no one can and should not disturb. The truth of belief in Islam, Judaism, Christianity, Catholicism, 
Hinduism, Buddhism, and Confucianism as religion is absolutely true for each of its adherents. At this level, the absolutisity of the truth of each religion does not need to be questioned, because it will certainly disturb the feelings of security and peace of mind of every adherent of each religion. This is what is called inward looking in each religion, each religious person looks more at his / her own religion. ${ }^{14}$

Second, at the social level in their interactions with other religions, it seems that the absoluticity of the truths of each religion should not be expressed outwardly. Why is that? In the perspective of Quraish Shihab, at the level of social interaction, absoluticity is the attitude of the soul inward, not demanding an outward statement or an outside reality that does not believe in it. In the Islamic context, these arguments have a doctrinaltheological basis as well as historical-sociological facts. When the polytheists in the 7th century AD insisted on rejecting the teachings of Islam, for the sake of mutual benefit, God ordered the Prophet Muhammad to say to them:

Say: "Who gives you sustenance, from the heavens and the earth?" Say: "It is Allah. and certain it is that either we or ye are on right guidance or in manifest error!" Say: "Ye shall not be questioned as to our sins, nor shall we be questioned as to what ye do." Say: "Our Lord will gather us together and will in the end decide the matter between us (and you) in truth and justice: and He is the one to decide, the One Who knows all". (Saba': 24-26) ${ }^{15}$

In the above verse, it can be seen that when absoluticity was brought out, the Prophet was not ordered to state what was inside (the belief about the absolute truth of Islamic teachings), but on the contrary the content of the verse stated: "Maybe we are right, maybe we are wrong, we leave it to God to decide. " Here, the attitude taught by the Koran is far more tolerant than the attitude expressed by some scholars who state: Ra'yuna showab wa yahtamilu khatho ', wa ro'yu ghoiruna khatho' wa yahtamilu showab"," Our opinion is correct even though it may be wrong. , and opinions other than us are wrong even though they may be true."16

In the rules of classical scholars, there is an explicit truth claim about one-sided truth (our opinion is correct) and the mistakes of other parties (your opinion is wrong). Meanwhile, the paradigm taught by the Koran is equality between the two parties: inna

\footnotetext{
${ }^{14}$ See M. Quraish Shihab Membumikan Al-Quran (Bandung: Mizan, 1997), p. 219; Compare also with the work of M. Quraish Shihab, Wawasan Al-Quran (Bandung: Mizan, 1997), p. 493-494.

15 Abdullah Yusuf Ali, Holy, p. 296-297.

${ }^{16}$ See Jalaluddin Rakhmat, Dahulukan Akhlak di atas Fikih (Bandung: Mutthahhari Press, 2003), p. 33.
} 
aw iyakum la'ala hudan aw fii dholalin mubin, "In fact we or you are in the real truth or heresy." For this reason, some commentators have named the style of language of the above verses with the term uslub al-inshaf, that is, the speaker does not openly blame his interlocutor, both are in an equal position: maybe we or you are right, and maybe we or you are the ones who wrong. ${ }^{17}$

Even in Quraish Shihab's view, from the above verse, there is a kind of tolerance towards the opinion of the interlocutor. Pay attention to His words: "You will not be asked about the sins that we have committed, and we will not be asked about what you did." What was done by the speaker, in this case the Prophet Muhammad and his followers, is described by the word ajromna / sin that we have committed, namely in the word sin and in the form of a past verb which implies that what is called sin has occurred. Meanwhile, when describing the actions of the interlocutor, in this case they have different beliefs with Muslims, their actions are not described with the word sin but with the sentence 'amma ta'malun / about what you are doing and will do, namely in what is very neutral. and in the present and future tenses of the verb. ${ }^{18}$

This paradigm is what contemporary Muslim scholars call external relativism, that is, when interacting at a social level with different religious parties, Muslims should not carry or impose the absolutes of their respective religious beliefs. ${ }^{19}$

If you observe some of the points about the principle of external relativism in the Islamic perspective above, this principle can serve as a guide that enriches the concept of religious moderation as well as harmony between religious communities in Indonesia. Because with the principle of external relativism, the Islamic perspective offers a concrete solution that Islam has the ability to accept religious differences. Although internally Islam acknowledges as a religion that is absolutely true, at the external level the truth of Islam does not negate the truth of other religions.

From here, a mutual understanding is needed for other religions that are different. This means that various religions in Indonesia, both Christianity, Catholicism, Hinduism, Buddhism, and Confucianism must have the ability to accept the beliefs of different religions in social interactions in the public sphere. Although internally, all of

\footnotetext{
${ }^{17}$ M. Quraish Shihab, Tafsir Al-Mishbah Vol 11 (Jakarta: Lentera Hati, 2007), p. 380.

18 Ibid., p. 381.

${ }^{19}$ Abdul Halim (ed.), Menembus Batas Tradisi (Jakarta: Kompas, 2006), p. 146-149.
} 
these religions recognize the absolute truth claims of their respective religions, externally the absoluteness of these beliefs does not negate the truth of other religions that are different.

It is at this point that as Muslims we must be humble. Because we are only able to grasp the truth of religion in a fragmentary way: only a fragment of meaning is scattered. When we speak of religious truth, in Hillary Lawson's language, our statement is really just an attempt to 'say the unsayable', to say something unspeakable. ${ }^{20}$ Let alone about the transcendent existence of God, regarding the dots of life as a profane reality, we often have difficulty describing them accurately and accurately, completely and finally.

Thus, one of the fundamental characteristics of our human condition is fragmentary or perspectivism. But don't get wrong. Perpsectivism is not relativism without truth values. Truth is not relative in the sense of right here and wrong there, but of perspectives: We only perceive truth from one perspective. ${ }^{21}$ The issue of relativism here is more related to methodological aspects, not to the metaphysical dimension. Relativism at this level is cultural relativism not substantial relativism. So relativism here is only technical-methodological in nature that is needed in building islamic brotherhood, tolerance, harmony, and even social cooperation between various Muslims who have different views.

\section{Closing}

It is this offer of the principle of external relativism that will provide a theological foundation for a more sympathetic, open and democratic dialogue between different religions; not apologetics that seek justification or claims of superiority between one religion over another. Because if the claim of superiority is maintained and explored outside, to other different parties, the consequence will be a clash, a clash between truths in different religions or let's say a kind of clash of truths occurs.

So once again, the principle of external relativism does not completely negate and eliminate the fundamental truth values that exist in every religion. The principle of external relativism only wants to be used as a method, or strategy in interacting with followers of various religions that the absolute truth of every religious adherent should

${ }^{20}$ F. Budi Hardiman, Filsafat Fragmentaris (Yogyakarta:Kanisius, 2007), p. 18.

${ }^{21}$ Brian Magee, Memoar Seorang Filosof, trans. Eko Prasetyo (Bandung: Mizan, 2005), p. XX. 
Mawaizh

Jurnal Dakwah dan Pengembangan Sosial Kemanusiaan

Vol. 11, no. 2 (2020), pp. 14-28.

DOI: https://doi.org/ 10.32923/maw.v11i2.1467

not be disclosed to other parties who are different, especially with truth claims about the absoluteness of one-sided beliefs and blame other parties. It is at this point that the principle of external relativism from an Islamic perspective is also very significant as a basis for dialogue, religious moderation, social cooperation, as well as to create harmony between religious communities in the Indonesian context. 


\section{BIBLIOGRAPHY}

Abu Zayd, Nasr Hamid. Mafhum al-Nash. Beirut: Markaz al-Saqafi al-'Arabi, 1994.

Abdullah, Amin. Dinamika Islam Kutural. Bandung: Mizan, 2000.

Harb, Ali. Kritik Kebenaran. Terj. Sunarwoto Dema. Yogyakarta: LkiS, 2004. . Hermeneutika Kebenaran. Terj. Sunarworo Dema. Yogyakarta: LkiS, 2003. . Kritik Nalar Al-Qur'an. Terj. M. Faisol Fatawi. Yogyakarta: LkiS, 2003.

Ali, Abdullah Yusuf, The Holy Qur'an, Text, Translation and Commentary. Maryland: Amana Corporation, 1983.

Hardiman, F. Budi. Filsafat Fragmentaris. Yogyakarta: Kanisius, 2007.

Halim, Abdul (ed.). Menembus Batas Tradisi. Jakarta: Kompas, 2006.

Haryatmoko. Dominasi Penuh Muslihat. Jakarta: Gramedia, 2010.

J. Sudarminta. Epistemologi Dasar. Yogyakarta: Pustaka Filsafat, 2002.

Madjid, Nurcholish. Masyarakat Religius. Jakarta: Paramadina, 2000.

Magee, Brian. Memoar Seorang Filosof. Terj. Eko Prasetyo. Bandung: Mizan, 2005.

Rakhmat, Jalaluddin. Dahulukan Akhlak di atas Fikih. Bandung: Mutthahhari Press, 2003.

Shihab, M. Quraish. Membumikan Al-Quran. Bandung: Mizan, 1997. . Tafsir Al-Mishbah Vol 11. Jakarta: Lentera Hati, 2007. . Wawasan Al-Quran. Bandung: Mizan, 1997.

Zaprulkhan. Signifikansi Epistemologi Pembacaan Hermeneutis Ali Harb. Yogyakarta: Idea Press, 2017. 